\title{
Budaya Organisasi, Kejelasan Sasaran Anggaran, Sistem Pelaporan dan Akuntabilitas Kinerja Instansi Pemerintah
}

\author{
Ni Wayan Dhevi Sukma Dewi ${ }^{1}$ \\ Fakultas Ekonomi dan Bisnis \\ Universitas Udayana, Indonesia
}

\author{
I Ketut Alit Suardana ${ }^{2}$ \\ Fakultas Ekonomi dan Bisnis \\ Universitas Udayana, Indonesia
}

\begin{abstract}
Surel : dhevisukma13@gmail.com
ABSTRAK

Akuntabilitas publik dan keterbukaan merupakan bagian dari prinsip-prinsip tata pemerintahan yang baik. Tujuan penelitian ini adalah mengetahui pengaruh budaya organisasi, kejelasan sasaran anggaran, dan sistem pelaporan pada akuntabilitas kinerja OPD Kabupaten Badung. Metode penelitian yang digunakan adalah metode survey dengan menyebarkan kuesioner kepada Kepala OPD, Kasubag Umum dan Keuangan, dan Kasubag Keuangan dan Akuntansi. Teknik analisis data yang digunakan adalah regresi linier berganda. Hasil penelitian menunjukkan bahwa kejelasan sasaran anggaran berpengaruh positif pada akuntabilitas kinerja. Sementara itu, budaya organisasi dan sistem pelaporan berpengaruh negatif pada akuntabiltas kinerja.
\end{abstract}

Kata Kunci: Budaya Organisasi; Kejelasan Sasaran Anggaran; Sistem Pelaporan; Akuntabilitas Kinerja Instansi Pemerintah.

\section{Organizational Culture, Budget Target Clarity, Reporting System and Accountability Performance}

\section{ABSTRACT}

Public accountability and openness are part of good governance principles. The aim of this research is to know the influence of organizational culture, the clarity of budget targets, and the reporting system on the performance accountability of Badung Regency OPD. The research methods used are survey methods by spreading questionnaires to the Head of OPD, Head of Sub Division of General and Planning, and Head of Sub Division of Financial and Accounting. The data analysis technique used is multiple linear regression. The results showed that the clarity of the budget target was positively influential in performance accountability. Meanwhile, organizational culture and reporting systems negatively affect performance accountability.

Keywords: Organizational Culture; Clarity Of Target Budgets; Reporting System; Government Agency Performance Accountability.

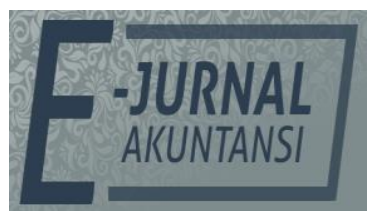

e-ISSN 2302-8556

Vol. 30 No. 12

Denpasar, Desember 2020

Hal. 3121-3135

DOI:

10.24843/EJA.2020.v30.i12.p10

PENGUTIPAN:

Dewi, N.W.D. \& Suardana, I

K.A. (2020). Budaya Organisasi,

Kejelasan Sasaran Anggaran,

Sistem Pelaporan dan

Akuntabilitas Kinerja Instansi

Pemerintah. E-Jurnal Akuntansi, 30(12), 3121-3135

RIWAYAT ARTIKEL:

Artikel Masuk:

27 Oktober 2020

Artikel Diterima:

9 Desember 2020

Artikel dapat diakses : https://ojs.unud.ac.id/index.php/Akuntansi/index 


\section{PENDAHULUAN}

Sebagai pelaksanaan UU Nomor 23 Tahun 2014 tentang Pemerintah Daerah, Pemerintah Daerah diberi kewenangan untuk mengatur dan mengurus sendiri urusan pemerintahan berdasarkan asas otonom dan tugas pembantuan. Berkaitan dengan hal tersebut, permasalahan yang dihadapi oleh pemerintah daerah pada umumnya berfokus pada ketidakefektifan, inefisiensi, dan penggunaan dana untuk kepentingan individu. Akuntabilitas merupakan kunci dalam mencapai good governance. Menurut Peraturan Presiden Republik Indonesia (Perpres RI) Nomor 29 Tahun 2014, diartikan sebagai perwujudan kewajiban suatu instansi pemerintah untuk mempertanggungjawabkan keberhasilan/kegagalan pelaksanaan program dan kegiatan yang telah diamanatkan para pemangku kepentingan dalam rangka mencapai misi organisasi secara terukur dengan sasaran/target kinerja yang telah ditetapkan melalui laporan kinerja instansi pemerintah yang disusun secara periodik. Akuntabilitas ini diwujudkan oleh pemerintah melalui suatu sistem yaitu Sistem Akuntabilitas Kinerja Instansi Pemerintah (SAKIP) yang implementasinya dimulai sejak penyusunan rencana strategi sampai dengan pertanggungjawaban dalam bentuk laporan kinerja (LAKIP).

Pembangunan Kabupaten Badung merupakan bagian integral dari pembangunan daerah Provinsi Bali serta pembangunan nasional. Pada tahun 2015, Kabupaten Badung berhasil mendapatkan nilai LAKIP sebesar 75,89 yang merupakan nilai AKIP tertinggi se-Provinsi Bali, NTB dan NTT. Sebelumnya, nilai LAKIP Kabupaten Badung pada tahun 2011 hanya sebesar 34,27 yang dikategorikan $C$ dan mengalami peningkatan pada tahun 2014 menjadi 69,12, serta rata-rata pencapaian sasaran kinerja Kabupaten Badung tahun 2016 sampai 2017 adalah sebesar 122,30 persen. Keberhasilan Kabupaten Badung dalam peningkatan hasil evaluasi LAKIP ini pula yang mengindikasikan bahwa Pemerintah Kabupaten Badung mampu menyediakan informasi keuangan yang diperlukan secara akurat, relevan, tepat waktu, konsisten dan dapat dipercaya serta struktur pengendalian intern terhadap SOP yang ada pada instansi berjalan secara optimal dan ditaati.

Dalam pencapaian good governance pada instansi pemerintah, tidak terlepas dari faktor internal organisasi, salah satunya adalah budaya organisasi. Budaya organisasi meliputi pandangan ataupun prinsip setiap anggota organisasi tersebut dalam hal bersikap dan berinteraksi satu sama lain sehingga budaya organisasi berdampak pada kinerja organisasi, bahkan mungkin merupakan faktor penting dalam menentukan keberhasilan dan kegagalan organisasi (Dewi et al., 2017). Pencapaian good governance di Indonesia yang masih rendah disebabkan oleh kurangnya perhatian pemerintah terhadap budaya organisasi. (Wijaya \& Akbar, 2013). Budaya organisasi dalam satu instansi pemerintah dengan instansi pemerintah lainnya dapat berbeda bergantung pada kondisi lingkungan kerja dalam instansi itu sendiri. Penelitian sebelumnya yang dilakukan oleh Gholami (2013), Chandra (2013), serta Hafidhah \& Herli (2014) menyatakan bahwa budaya organisasi 
berpengaruh terhadap kinerja organisasi, dengan simpulan signifikansi yang berbeda.

Dalam menghadapi akuntabilitas, pemerintah perlu memperhatikan beberapa hal, antara lain anggaran, pengendalian akuntansi, efektivitas pelaksanaan anggaran dan sistem pelaporan. Anggaran merupakan pernyataan mengenai estimasi kinerja yang hendak dicapai selama periode waktu tertentu yang dinyatakan dalam ukuran finansial (Suwandi, 2013). Salah satu karakteristik anggaran adalah kejelasan sasaran anggaran. Kejelasan sasaran anggaran merupakan sejauh mana tujuan anggaran ditetapkan secara jelas dan spesifik dengan tujuan agar anggaran tersebut dapat dimengerti oleh orang bertanggung jawab atas pencapain sasaran anggaran tersebut (Yulianti, 2014). Adanya kejelasan sasaran anggaran secara spesifik akan mempermudah untuk mempertanggungjawabkan keberhasilan atau kegagalan pelaksanaan tugas organisasi sehingga mendorong pegawai untuk melakukan yang terbaik dalam rangka mencapai tujuan dan sasaran yang telah ditetapkan sebelumnya. Hasil penelitian oleh Dewi \& Supadmi (2015), Fauzan (2017), Pangumbalerang (2014) dan Triuriana (2013) adalah kejelasan sasaran anggaran berpengaruh positif terhadap akuntabilitas kinerja instansi pemerintah. Namun, Darwanis \& Chairunnisa (2013) menyimpulkan bahwa kejelasan sasaran anggaran tidak berpengaruh terhadap akuntabilitas kinerja instansi pemerintah Aceh.

Akuntabilitas melalui anggaran meliputi penyusunan anggaran sampai dengan pelaporan anggaran (Paramitha \& Gayatri, 2016). Sistem pelaporan yang baik diperlukan agar dapat memantau dan mengendalikan kinerja manajer dalam mengimplementasikan anggaran yang telah ditetapkan. Laporan umpan balik (feedback) diperlukan untuk mengukur aktivitas-aktivitas yang dilaksanakan dalam rangka meningkatkan kinerja dan akuntabilitas pada pelaksanaan suatu rencana atau waktu mengimplementasikan suatu anggaran, sehingga manajemen dapat mengetahui hasil dari pelaksanaan rencana atau pencapaian sasaran anggaran yang ditetapkan. Pemerintah daerah selaku pengelola dana publik harus mampu menyediakan informasi keuangan yang diperlukan secara akurat, relevan, tepat waktu, konsisten, dan dapat dipercaya (Eivani et al., 2012). Penelitian oleh Paramitha \& Gayatri (2016), Yulianti (2014) dan Triuriana (2013) menyatakan bahwa sistem pelaporan berpengaruh pada akuntabilitas kinerja instansi pemerintah. Keutamaan budaya organisasi merupakan pengendali dan arah dalam membentuk sikap dan perilaku manusia yang melibatkan diri dalam suatu kegiatan organisasi. Mengingat budaya organisasi merupakan suatu kesepakatan bersama para anggota dalam suatu organisasi atau perusahaan sehingga mempermudah lahirnya kesepakatan yang lebih luas untuk kepentingan perorangan. Teori stewardship menjelaskan bahwa manajemen tidak termotivasi oleh tujuan- tujuan individu. Hal ini dapat menciptakan sebuah budaya organisasi yang baik sehingga akan mendukung terwujudnya akuntabilitas kinerja yang tinggi dalam instansi pemerintah, yaitu Organisasi Pemerintah Daerah Kabupaten Badung.

Teori stewardship merupakan penggambaran mengenai penatalayanan dimana kaitannya terhadap organisasi di dalam kepemerintahan, sehingga 
dengan tujuan penatalayanan tersebut, akan terbentuk budaya organisasi yang terfokus pada pelayanan masyarakat sehingga pencapaian kinerja instansi pemerintah akan meningkat.

$\mathrm{H}_{1}$ : Budaya organisasi berpengaruh positif pada akuntabilitas kinerja instansi pemerintah daerah Kabupaten Badung.

Penelitian seperti Primayoni et al., (2014), Pangumbalerang \& Pinatik, (2014), dan Anjarwati (2012) menunjukkan adanya pengaruh positif antara kejelasan sasaran anggaran terhadap akuntabilitas kinerja instansi pemerintah. Anggaran daerah harus bisa menjadi tolak ukur pencapaian akuntabilitas kinerja yang diharapkan, sehingga perencanaan anggaran daerah harus bisa menggambarkan sasaran kinerja secara jelas. Kejelasan sasaran anggaran merupakan sejauh mana tujuan anggaran ditetapkan secara jelas dan spesifik dengan tujuan agar anggaran tersebut dapat dimengerti oleh orang yang bertanggung-jawab atas pencapaian sasaran anggaran tersebut. Oleh sebab itu, sasaran anggaran daerah harus dinyatakan secara jelas, spesifik dan dapat dimengerti oleh mereka yang bertanggung-jawab untuk melaksanakannya (Fauzan, 2017). Pelaksana anggaran memberikan reaksi positif dan secara relatif sangat kuat untuk meningkatkan kejelasan sasaran anggaran. Reaksi tersebut adalah peningkatan kepuasan kerja, penurunan ketegangan kerja, peningkatan sikap karyawan terhadap anggaran, kinerja anggaran dan efisiensi biaya pada pelaksana anggaran secara signifikan, jika sasaran anggaran dinyatakan secara jelas (Kaltsum \& Abdul, 2012). Hal ini berimplikasi pada peningkatan akuntabilitas kinerja.

$\mathrm{H}_{2}$ : Kejelasan sasaran anggaran berpengaruh positif pada akuntabilitas kinerja instansi pemerintah daerah Kabupaten Badung.

Sistem pelaporan yang baik diperlukan agar dapat memantau dan mengendalikan kinerja manajerial dalam mengimplementasikan anggaran yang telah ditetapkan. Pemerintah daerah selaku pengelola dana publik harus mampu menyediakan informasi keuangan yang diperlukan secara akurat, relevan, tepat waktu, konsisten dan dapat dipercaya (Setiawan et al., 2013). Dalam agency theory dijelaskan bahwa banyak terjadi information asymmetry antara pihak agent (pemerintah) dengan pihak principal (masyarakat). Adanya information asymmetry inilah yang memungkinkan terjadinya penyalahgunaan wewenang oleh pihak agen. Oleh karena itu, diperlukan Laporan Akuntabilitas Kinerja Instansi Pemerintah (LAKIP) sebagai sarana pelaporan yang dibuat melalui sebuah sistem yang jelas dan terintegritas. Dalam penyusunan LAKIP, pemerintah daerah harus memiliki sistem pelaporan yang memadai dan didukung dengan kualtiasmpengendalian internal yang baik atas kinerjanya sebagai mekanisme checks and balances.

$\mathrm{H}_{3}$ : Sistem pelaporan anggaran berpengaruh positif pada akuntabilitas kinerja instansi pemerintah daerah Kabupaten Badung.

\section{METODE PENELITIAN}

Pendekatan yang digunakan dalam penelitian ini adalah pendekatan kuantitatif yang berbentuk asosiatif. Penelitian ini mengambil lokasi di Organisasi Pemerintah Daerah Kabupaten Badung. Kabupaten Badung dipilih sebagai lokasi penelitian karena terjadi peningkatan nilai LAKIP sebesar 35,12 persen 
dari tahun 2011 ketahun 2014, serta rata-rata pencapaian sasaran kinerja Kabupaten Badung tahun 2016 sampai 2017 adalah sebesar 122,30 persen. Objek pada penelitian ini adalah akuntabilitas kinerja pada Organisasi Perangkat Daerah Kabupaten Badung. Adapun variabel yang digunakan dalam penelitian ini, yaitu variabel terikat dan variabel bebas. Akuntabilitas kinerja instansi pemerintah $(Y)$ sebagai variabel terikat (dependent variable), sedangkan budaya organisasi $\left(X_{1}\right)$, kejelasan sasaran anggaran $\left(X_{2}\right)$, dan sistem pelaporan $\left(\mathrm{X}_{3}\right)$ sebagai variabel bebas (independent variable).

Penelitian ini menggunakan jenis data kuantitatif berupa hasil scoring jawaban responden terhadap kuesioner yang telah disebar yang diukur dengan skala likert. Data primer dalam penelitian ini berupa informasi yang dikumpulkan berdasarkan jawaban responden terhadap kuesioner dan data sekunder yang digunakan dalam penelitian ini adalah data-data seperti gambaran umum, visi misi Kabupaten Badung, dan daftar Organisasi Perangkat Daerah Kabupaten Badung yang diperoleh dari http:/ / Badungkab.go.id.

Populasi dalam penelitian ini adalah seluruh Organisasi Pemerintah Daerah (OPD) di Kabupaten Badung sejumlah 40 OPD. Adapun metode penentuan sampel menggunakan pendekatan sampel jenuh yaitu peneliti menjadikan seluruh populasi sebagai sampel yaitu 40 OPD yang ada di Kabupaten Badung. Responden dalam penelitian ini adalah Kepala OPD, Kepala Sub Bagian Umum dan Perencanaan, serta Kepala Sub Bagian Keuangan dan Akuntansi karena dianggap mampu menggambarkan keseluruhan kinerja instansi pemerintahan daerah dan secara langsung terlibat dalam penyusunan anggaran dan laporan keuangan.

Metode pengumpulan data yang digunakan dalam penelitian adalah metode survei dengan menyebar kuesioner. Kuesioner diberikan secara langsung kepada OPD Kabupaten Badung. Teknik analisis data yang digunakan adalah regresi linier berganda untuk mengukur pengaruh antara variabel bebas terhadap variabel terikat. Hasil analisis regresi adalah berupa koefisien untuk masing-masing variabel independen. Persamaan regresi linier berganda yang digunakan dalam penelitian ini adalah sebagai berikut.

$Y=a 0+\beta 1 X 1+\beta 2 X 2+\beta 3 X 3+\varepsilon$

Dimana:

$$
\begin{array}{ll}
\mathrm{Y} & =\text { Akuntabilitas Kinerja Instansi Pemerintah } \\
\mathrm{a} 0 & =\text { Konstanta } \\
\mathrm{B} 1-\mathrm{B} 4 & =\text { Koefisien Regresi } \\
\mathrm{X} 1 & =\text { Budaya Organisasi } \\
\mathrm{X} 2 & =\text { Kejelasan Sasaran Anggaran } \\
\mathrm{X} 3 & =\text { Sistem Pelaporan Anggaran } \\
\varepsilon & =\text { Standar Error }
\end{array}
$$

\section{HASIL DAN PEMBAHASAN}

Perhitungan hasil penelitian dilakukan dengan analisis regresi linier berganda melalui software SPSS for Windows dengan hasil yang dapat dilihat pada tabel berikut. 
Tabel 1. Hasil Uji Validitas

\begin{tabular}{|c|c|c|c|}
\hline Variabel & $\begin{array}{c}\text { Kode } \\
\text { Instrumen }\end{array}$ & $\begin{array}{c}\text { Nilai Pearson } \\
\text { Correlation }\end{array}$ & Keterangan \\
\hline \multirow{10}{*}{ Budaya Organisasi } & $\mathrm{X} 1.1$ & 0,487 & Valid \\
\hline & $\mathrm{X} 1.2$ & 0,49 & Valid \\
\hline & X1.3 & 0,506 & Valid \\
\hline & X1.4 & 0,611 & Valid \\
\hline & X1.5 & 0,503 & Valid \\
\hline & X1.6 & 0,539 & Valid \\
\hline & X1.7 & 0,617 & Valid \\
\hline & X1.8 & 0,478 & Valid \\
\hline & X1.9 & 0,506 & Valid \\
\hline & X1.10 & 0,541 & Valid \\
\hline \multirow[t]{15}{*}{ Kejelasan Sasaran Anggaran } & $\mathrm{X} 2.1$ & 0,602 & Valid \\
\hline & $\mathrm{X} 2.2$ & 0,463 & Valid \\
\hline & $\mathrm{X} 2.3$ & 0,410 & Valid \\
\hline & $\mathrm{X} 2.4$ & 0,479 & Valid \\
\hline & $\mathrm{X} 2.5$ & 0,510 & Valid \\
\hline & $\mathrm{X} 2.6$ & 0,494 & Valid \\
\hline & $\mathrm{X} 2.7$ & 0,538 & Valid \\
\hline & $\mathrm{X} 2.8$ & 0,618 & Valid \\
\hline & $\mathrm{X} 2.9$ & 0,657 & Valid \\
\hline & $X 2.10$ & 0.594 & Valid \\
\hline & $X 2.11$ & 0,529 & Valid \\
\hline & $\mathrm{X} 2.12$ & 0,535 & Valid \\
\hline & $\mathrm{X} 2.13$ & 0,419 & Valid \\
\hline & $\mathrm{X} 2.14$ & 0,663 & Valid \\
\hline & X2.15 & 0,503 & Valid \\
\hline \multirow[t]{5}{*}{ Sistem Pelaporan } & X3.1 & 0,554 & Valid \\
\hline & $\mathrm{X} 3.2$ & 0,615 & Valid \\
\hline & X3.3 & 0,759 & Valid \\
\hline & X3.4 & 0,599 & Valid \\
\hline & X3.5 & 0,704 & Valid \\
\hline
\end{tabular}

Sumber: Data Penelitian, 2019

Pengujian validitas dilakukan terhadap 116 responden. Tabel 1, menunjukkan bahwa seluruh item pernyataan pada setiap variabel budaya organisasi, kejelasan sasaran anggaran, sistem pelaporan, dan akuntabilitas kinerja instansi pemerintah adalah valid. Hal ini ditunjukkan oleh nilai pearson correlation dari seluruh indikator tersebut lebih besar dari 0.30 .

Uji reliabilitas atau uji keandalan instrumen dilakukan untuk menguji konsistensi jawaban responden atas seluruh butir atau item pernyataan yang digunakan. Uji reliabilitas dilakukan terhadap seluruh instrumen dengan koefisien cronbach's alpha $\geq 0,60$, maka instrumen yang digunakan reliable (Sugiyono, 2017: 199). Kuesioner dikatakan memenuhi uji reliabilitas jika nilai dari cronbach's alpha $\geq 0,60$. Adapun hasil uji reliabilitas dapat dilihat pada Tabel 2.

Berdasarkan Tabel 2, dapat dilihat bahwa masing-masing variabel mempunyai nilai cronbach's alpha lebih besar dari 0.60, yang artinya 
seluruh pernyataan dalam kuesioner penelitian ini telah memenuhi syarat reliabilitas dan dapat digunakan.

Tabel 2. Hasil Uji Reliabilitas

\begin{tabular}{lcc}
\multicolumn{1}{c}{ Variabel } & Conbrach's Alpha & Keterangan \\
\hline Budaya Organisasi & 0,703 & Reliabel \\
Kejelasan Sasaran Anggaran & 0,817 & Reliabel \\
Sistem Pelaporan & 0,648 & Reliabel \\
Akuntabilitas Kinerja Instansi Pemerintah & 0,659 & Reliabel \\
\hline
\end{tabular}
Sumber: Data Penelitian, 2019

Uji normalitas bertujuan untuk menguji apakah residual model regresi berdistribusi normal atau tidak. Uji normalitas dalam pengujian ini menggunakan metode Kolmogrov-Smirnov. Data penelitian dapat dikatakan berdistribusi normal apabila nilai Asymp. Sig (2-tailed) lebih besar daripada level of significant yang dipakai yaitu $0,05(\alpha=0.05)$. Adapun hasil uji normalitas dengan metode Kolmogrov-Smirnov disajikan pada Tabel 3.

Tabel 3 Hasil Uji Normalitas

\begin{tabular}{llr}
\hline $\mathrm{N}$ & & \\
\hline Normal Parameters & Mean & 116 \\
& Std. Deviation & 0,0000000 \\
Most Extreme Differences & Absolute & 2,55914408 \\
& Positive & 0,046 \\
& Negattive & 0,034 \\
Test Statistic & & $-0,046$ \\
Asymp. Sig. (2-tailed) & & 0,046 \\
\hline Suber. Data Pene & 0,200 \\
\hline
\end{tabular}

Sumber: Data Penelitian, 2019

Hasil uji normalitas pada Tabel 3, menunjukkan nilai Asymp. Sig (2tailed) sebesar 0,200 yang lebih besar dari 0,05, sehingga data dalam penelitian ini berdistribusi normal.

Uji multikolinearitas bertujuan untuk menguji apakah pada model regresi ditemukan adanya korelasi antar variabel bebas. Multikolinearitas terjadi apabila tolerance value di atas $10 \%$ atau nilai VIF di bawah 10 . Hasil uji multikolinearitas dapat dilihat pada table 4 .

Tabel 4. Hasil Uji Multikolinearitas

\begin{tabular}{lll}
\hline \multicolumn{1}{c}{ Variabel } & Tolerance & VIP \\
\hline Budaya Organisasi & 0,575 & 1,738 \\
Kejelasan Sasaran Anggaran & 0,489 & 2,043 \\
Sistem Pelaporan & 0,799 & 1,251 \\
\hline Sur
\end{tabular}

Sumber: Data Penelitian, 2019

Berdasarkan Tabel 4, nilai Tolerance yang dimiliki oleh setiap variabel bebas yaitu budaya organisasi, kejelasan sasaran anggaran, dan sistem pelaporan masing-masing adalah sebesar 0,575; 0,489; dan 0,799 yang seluruhnya lebih besar dari $10 \%$ atau 0,1 . Apabila dilihat dari nilai VIF masingmasing variabel yaitu sebesar 1,738; 2,043; dan 1,251 yang juga telah bebas dari multikolinearitas karena memiliki nilai kurang dari 10. Dilihat dari hasil uji multikolinearitas tersebut, makan dapat disimpulkan bahwa tidak ada multikolinearitas antar variabel bebas dalam model regresi.

Uji Heteroskedastisitas bertujuan untuk menguji apakah dalam regresi 
terjadi ketidaksamaan varians dan residual satu pengamatan ke pengamatan yang lain. Pengujian heteroskedastisitas dilakukan dengan uji glejser, dengan cara meregresi nilai absolute residual dari model yang diestimasi terhadap variabel bebas. Jika nilai signifikannya $\geq 0,05$ maka tidak terjadi gejala heteroskedastisitas. Hasil uji heteroskedastisitas dapat dilihat pada Tabel 5.

Tabel 5. Hasil Uji Heteroskedastisitas

\begin{tabular}{lc}
\hline \multicolumn{1}{c}{ Variabel } & Sig \\
\hline Budaya Organisasi & 0,48 \\
Kejelasan Sasaran Anggaran & 0,298 \\
Sistem Pelaporan & 0,925 \\
\hline
\end{tabular}

Sumber: Data Penelitian, 2019

Tabel 5, menunjukkan bahwa nilai signifikansi masing-masing variabel pada model regresi besarnya $\geq 0,05$ yang artinya model regresi dalam penelitian ini bebas dari gejala heteroskedastisitas.

Analisis regresi linier berganda (Multiple Regression Analysis) digunakan untuk mengetahui pengaruh satu atau lebih variabel bebas atau independen terhadap variabel terikat atau dependen. Adapun hasil analisis regresi linier berganda dapat dilihat pada Tabel 6 .

Tabel 6. Hasil Regresi Linear Berganda

\begin{tabular}{|c|c|c|c|c|c|}
\hline \multirow[t]{2}{*}{ Model } & \multicolumn{2}{|c|}{$\begin{array}{l}\text { Unstandardized } \\
\text { Coefficients }\end{array}$} & \multirow{2}{*}{$\begin{array}{c}\text { Standardized } \\
\text { Coefficients } \\
\text { Beta }\end{array}$} & \multirow[t]{2}{*}{$\mathrm{t}$} & \multirow[t]{2}{*}{ Sig. } \\
\hline & B & Std. Error & & & \\
\hline (Constant) & 15,281 & 3,239 & & 4,719 & 0,000 \\
\hline Budaya Organisasi & $-0,083$ & 0,112 & $-0,072$ & $\begin{array}{c}- \\
0,742\end{array}$ & 0,459 \\
\hline $\begin{array}{l}\text { Kejelasan Sasaran } \\
\text { Anggaran }\end{array}$ & 0,478 & 0,075 & 0,677 & 6,405 & 0,000 \\
\hline Sistem Pelaporan & $-0,039$ & 0,154 & $-0,021$ & $\begin{array}{c}- \\
0,257\end{array}$ & 0,798 \\
\hline
\end{tabular}

Sumber: Data Penelitian, 2019

Dari hasil analisis regresi linier berganda dapat dibentuk persamaan regresi penelitian sebagai berikut

$$
Y=15,281-0,083 X_{1}+0,478 X_{2}-0,039 X_{3}
$$

Persamaan 2, menunjukkan nilai konstanta (a) adalah sebesar 15,281, yang berarti apabila variabel budaya organisasi, kejelasan sasaran anggaran, dan sistem pelaporan dinyatakan konstan pada angka 0 , maka nilai akuntabilitas kinerja instansi pemerintah akan tetap terjadi. Nilai koefisien regresi variabel budaya organisasi (B1) sebesar -0,083. Nilai koefisien yang negatif tersebut menunjukkan bahwa variabel budaya organisasi berbanding terbalik dengan variabel akuntabilitas kinerja instansi publik. Hal ini berarti bahwa setiap kenaikan nilai variabel budaya organisasi maka nilai akuntabilitas kinerja instansi pemerintah akan mengalami penurunan sebesar, dengan asumsi variabel bebas lainnya konstan. Nilai koefisien regresi variabel kejelasan sasaran anggaran (B2) sebesar 0,478. Nilai positif dari koefisien regresi tersebut menunjukkan bahwa variabel kejelasan sasaran anggaran sebanding dengan variabel akuntabilitas kinerja instansi publik. Hal ini berarti bahwa apabila terjadi kenaikan nilai variabel kejelasan sasaran anggaran, maka akan 
diikuti oleh kenaikan nilai dari variabel akuntabilitas kinerja instansi publik dengan anggapan variabel bebas lainnya konstan. Nilai koefisien regresi variabel sistem pelaporan (B3) sebesar $-0,039$. Nilai koefisien yang bernilai negatif menunjukkan bahwa variabel sistem pelaporan berbanding terbalik dengan variabel akuntabilitas kinerja instansi publik.

Tabel 7. Hasil Uji Koefisien Determinasi

\begin{tabular}{|c|c|c|c|c|}
\hline Model & $R$ & $R$ Sauare & Adiutud $D C$ & d. Error of the \\
\hline 1 & 0623 & 0388 & 0372 & 2593 \\
\hline
\end{tabular}

Sumber: Data Penelitian, 2019

Uji koefisien determinasi digunakan untuk mengukur seberapa jauh kemampuan model dalam menerapkan variabel-variabel dependen. Koefisien determinasi yang digunakan pada analisis regresi adalah nilai Adjusted $\mathrm{R}^{2}$. Tabel 7, menunjukkan bahwa nilai koefisien determinasi atau Adjusted $\mathrm{R}^{2}$ adalah sebesar 0,372. Hasil ini berarti bahwa 37,2\% variasi akuntabilitas kinerja instansi pemerintah pada OPD Kabupaten Badung dapat dijelaskan oleh variabel budaya organisasi, kejelasan sasaran anggaran, dan sistem pelaporan, sedangkan 62,8\% sisanya dijelaskan oleh faktor lainnya yang tidak dimasukkan ke dalam model penelitian ini.

Uji kelayakan model atau uji $\mathrm{F}$ pada dasarnya mengetahui kelayakan model regresi linier berganda sebagai alat analisis untuk menguji pengaruh variabel independen pada variabel dependen. Apabila nilai tingkat signifikansi $\mathrm{F}<\mathrm{a}=0,05$, maka model ini dapat dikatakan layak uji, begitu pula sebaliknya, jika nilai tingkat signifikansi $\mathrm{F} \geq \mathrm{a}=0,05$ maka model persamaan regresi dikatakan tidak layak uji. (Ghozali, 2016:96). Hasil Uji F dapat dilihat pada Tabel 8 .

Tabel 8. Hasil Uji Kelayakan Model (Uji F)

\begin{tabular}{ccccccc}
\hline & Model & Sum of & $d f$ & Mean & $F$ & Sig. \\
& Squares & & Square \\
& Regression & 477,7019513 & 3 & 159,234 & 23,67917 & 0.000 \\
& Residual & 753,160 & 112,000 & 6,725 & & \\
\hline
\end{tabular}

Sumber: Data Penelitian, 2019

Tabel 8, menunjukkan bahwa nilai Sig.F sebesar 0,000 lebih kecil daripada 0,05. Hal ini berarti bahwa model regresi yang terbentuk layak digunakan sebagai alat analisis dalam menguji pengaruh variabel independen pada variabel dependen yang digunakan dalam penelitian ini.

Uji statistik $t$ dilakukan untuk mengetahui pengaruh masing-masing variabel independen secara individual pada variabel dependen, dengan taraf siginifikansi 0.05 . Jika probabilitas nilai $\mathrm{t}$ atau signifikansi $\leq 0,05$ maka dapat dikatakan bahwa terdapat pengaruh antara variabel bebas pada variabel terikat. Jika probabilitas nilai $\mathrm{t}$ atau signifikansi $\geq 0,05$ maka dapat dikatakan bahwa tidak terdapat pengaruh antara variabel bebas pada variabel terikat. Adapun hasil uji t disajikan pada Tabel 9.

Tabel 9, menunjukkan hasil pengujian hipotesis. Pengujian hipotesis 1, variabel budaya organisasi memiliki nilai koefisien beta negatif sebesar $-0,742$ dengan nilai signifikansi sebesar $0,459>0,05$. Hal ini menunjukkan bahwa budaya organisasi tidak berpengaruh pada akuntabilitas kinerja instansi 
pemerintah di OPD Kabupaten Badung, sehingga $\mathrm{H}_{1}$ ditolak. Tingginya kualitas budaya organisasi pada sebuah instansi pemerintah tidak akan menghapus risiko-risiko terjadinya penggunaan unsur kepentingan yang sejalan dengan teori agency dan dapat menyebabkan penyalahgunaan wewenang, baik dalam penyusunan anggaran maupun pelaporan pencapaian kinerja instansi yang akan berdampak pada tingkat akuntabilitas kinerja instansi pemerintah. Hasil penelitian ini berbeda dengan apa yang dilakukan oleh Khasanah (2016) yang menyatakan bahwa budaya organisasi berpengaruh positif dan signifikan terhadap akuntabilitas kinerja instansi pemerintah di Kota Surakarta. Hal ini dapat disebabkan oleh berbedanya lingkungan dan persepsi setiap individu dalam instansi pemerintah itu sendiri. Hasil penelitian yang menghasilkan kesimpulan berbeda ini kemungkinan disebabkan oleh belum maksimalnya upaya pimpinan OPD maupun pegawai untuk bersamasama menciptakan integritas yang baik dalam budaya organisasinya.

\section{Tabel 9. Hasil Uji Statistik $t$}

\begin{tabular}{|c|c|c|}
\hline Variabel & $T$ & Sig. \\
\hline (Constant) & 4,719 & 0,000 \\
\hline Budaya Organisasi & $-0,742$ & 0,459 \\
\hline Kejelasan Sasaran Anggaran & 6,405 & 0,000 \\
\hline Sistem Pelaporan & $-0,257$ & 0,798 \\
\hline
\end{tabular}

Sumber: Data Penelitian, 2019

Pengujian hipotesis 2, variabel kejelasan sasaran anggaran memiliki nilai koefisien beta positif sebesar 6,405 dengan nilai signifikansi sebesar $0,000 \leq 0,05$. Hal ini menunjukkan bahwa kejelasan sasaran anggaran berpengaruh positif dan secara parsial pada akuntabilitas kinerja instansi pemerintah di OPD Kabupaten Badung, sehingga $\mathrm{H}_{2}$ diterima. Penyusunan anggaran secara jelas dan spesifik meningkatkan produktivitas pegawai dalam pekerjaannya. Selain itu kejelasan sasaran anggaran akan mempermudah instansi pemerintah untuk mempertanggungjawabkan kinerjanya sehingga akan meningkatkan tingkat akuntabilitas kinerja instansi pemerintah. Hal ini akan mengatasi adanya asimetri informasi yang dijelaskan oleh agency theory karena semakin jelas dan spesifik anggaran yang disusun, maka akan semakin jelas pelaporannya sehingga dapat mengurangi asimetri informasi yang terjadi antara pemerintah sebagai agen dan masyarakat sebagai principle. Hasil penelitian ini sejalan dengan hasil penelitian sebelumnya yang dilakukan oleh Primayoni et al., (2014), Pangumbalerang \& Pinatik (2014), dan Anjarwati (2012).

Pengujian hipotesis 3 menunjukkan bahwa variabel sistem pelaporan memiliki nilai koefisien beta negatif sebesar -0,257 dengan nilai signifikansi sebesar 0,798 >0,05. Hal ini menunjukkan bahwa budaya organisasi tidak berpengaruh pada akuntabilitas kinerja instansi pemerintah di OPD Kabupaten Badung, sehingga $\mathrm{H}_{3}$ ditolak. Sistem pelaporan meliputi ketepatan waktu dan keakuratan laporan yang dihasilkan, ketersediaan data yang dapat diakses secara real, dan analisis dari isi laporan kinerja itu sendiri. Sistem pelaporan tidak akan berjalan baik apabila tidak didukung oleh komitmen dan intergitas tiap individu untuk bertindak sesuai dengan sistem yang diterapkan. Hasil penelitian ini sejalan dengan 
penelitian sebelumnya yang dilakukan oleh Setiawan et al., (2013) yang menunjukkan sistem pelaporan anggaran tidak berpengaruh terhadap akuntabilitas kinerja instansi pemerintah. Nanum berbeda dengan hasil penelitian dari Paramitha \& Gayatri, (2016), Yulianti (2014) dan Triuriana (2013) menyatakan bahwa sistem pelaporan berpengaruh positif pada akuntabilitas kinerja instansi pemerintah. Hasil penelitian yang tidak berpengaruh signifikan ini kemungkinan disebabkan oleh adanya kondisi di mana pemerintah daerah Kabupaten Badung belum mampu memaksimalkan sistem pelaporan yang tersedia untuk mengembangkan akuntabilitas kinerjanya menjadi lebih baik lagi.

\section{SIMPULAN}

Berdasarkan hasil dan pembahasan penelitian, dapat disimpulkan bahwa Budaya organisasi berpengaruh negatif pada akuntabilitas kinerja instansi pemerintah daerah, ini berarti hipotesis pertama dari peneliti ditolak. Hal ini menjelaskan budaya organisasi yang baik dalam suatu organisasi pemerintah dapat berdampak penurunan akuntabilitas kinerja instansi pemerintah. Sedangkan, kejelasan sasaran anggaran berpengaruh positif pada akuntabilitas kinerja instansi pemerintah daerah Kabupaten Badung, ini berarti hipotesis kedua dari peneliti diterima. Hal ini menjelaskan bahwa semakin anggaran disusun secara jelas dan terperinci, maka semakin jelas pula informasi mengenai pencapaian kinerja instansi pemerintah daerah, yang akan berdampak pada peningkatan akuntabilitas kinerja instansi pemerintah. Sistem pelaporan berpengaruh negatif pada akuntabilitas kinerja instansi pemerintah daerah Kabupaten Badung, ini berarti hipotesis ketiga dari peneliti ditolak. Hal ini menjelaskan bahwa sistem pelaporan yang diterapkan berdampak pada penurunan akuntabilitas kinerja instansi pemerintah.

Adapun saran-saran yang dapat diberikan dalam penelitian ini yaitu penelitian ini menunjukkan nilai adjusted $\mathrm{R}^{2}$ sebesar 0,372 . Ini berarti tingkat akuntabilitas kinerja instansi pemerintah dapat dijelaskan oleh variabel budaya organisasi, kejelasan sasaran anggaran, dan sistem pelaporan sebesar $37,2 \%$, sedangkan $62,8 \%$ sisanya dijelaskan oleh faktor lain yang tidak diuji dalam penelitian ini. Peneliti selanjutnya disarankan untuk menambah beberapa variabel lain dapat memengaruhi tingkat akuntabilitas kinerja instansi pemerintah serta memperluas objek penelitian dengan cara memilih lokasi penelitian yang berbeda. Sementara itu, bagi OPD Kabupaten Badung, sebaiknya para atasan melakukan upaya lebih dalam penciptaan budaya organisasi yang lebih baik serta melakukan peningkatan kompetensi masingmasing individu serta pengawasan evaluasi yang lebih ketat mengenai sistem pelaporan yang diterapkan di instansinya. Hal tersebut bertujuan untuk memaksimalkan jalannya sistem pelaporan yang melibatkan seluruh OPD dan pihak lain yang berkepentingan dalam rangka mendukung dan melaksanakan AKIP sesuai ketentuan peraturan perundang-undangan yang berlaku. 


\section{REFERENSI}

Anjarwati, M. (2012). Pengaruh Kejelasan Sasaran Anggaran, Pengendalian Akuntansi, dan Sistem Pelaporan Terhadap Akuntabilitas Kinerja Instansi Pemerintah. Accounting Analysis Journal, 1(2), 15-27.

Ahmad, M. Shakil. (2012). Impact of Organizational Culture on Performance Management Practices in Pakistan. Business Intelligence Journal. January, 2012 Vol.5 No.1

Akbar, Rusdi, Mesri Welhelmina. (2014). Accountability And Performance: Evidence From Local Government. Journal of Indonesian Economy and Business, 29 (1), pp:56-73

Chandra, L. A. (2013). Pengaruh Budaya Organisasi Terhadap Kinerja Pegawai Kantor Ketahanan Pangan dan Penyuluhan Kabupaten Kutai Barat. EJournal Administrasi Negara, 1(3), 885-889.

Darwanis, \& Chairunnisa, S. (2013). Akuntabilitas Kinerja Instansi Pemerintah. Jurnal Telaah \& Riset Akuntansi, 6(1), 54-63.

Dewi, A., Riska, P., \& Putri, I. G. A. M. A. D. (2017). Pengaruh Kebijakan Dividen Pada Nilai Perusahaan Dengan Pengungkapan CSR Dan Good Corporate Governance Sebagai Pemoderasi. E-Jurnal Akuntansi Universitas Udayana, 21(1), 173-199.

Dewi, M. A. P., \& Supadmi, N. L. (2015). Pengaruh Ketepatan Anggaran Dan Pengendalian Manajerial Sektor Publik Pada Akuntabilitas Kinerja SKPD. E-Jurnal Akuntansi, 12(1), 50-63.

Emrinaldi,N. D. P., Susilowati, Enny, Mardjono. (2015). An Investigation of the effect of Accounting Controls, Budget Goal Clarity, Mental Model Implementation on Accountability of Government Performance. Journal of Economics, Business and Accounting Ventura Vol.18, No 3, December 2015- March 2016, pages 198 - 215Farzad Eivani. (2012). Public accountability and government financial reporting. African Journal of Business Management, 6(29).

Eivani, F., Kamran, N., Mostafa E. 2012. Public Accountability And Government Financial Reporting. African Journal of Business Management, 6 (29), pp:8475-8482

Fauzan, R. H. (2017). Pengaruh Kejelasan Sasaran Anggaran, Pengendalian Akuntansi, Sistem Pelaporan Dan Penerapan Akuntabilitas Keuangan Terhadap Akuntabilitas Kinerja Instansi Pemerintah (AKIP). JOM Fekon, 4(1), 1122-1136.

Gholami, S., \& Sadri, M. (2013). The Relationship Between Organizational Commitment of Physical Education Teachers Mazandaran Province. International Research Journal of Applied and Basic Science, 6(10), 14301434.

Ghozali, Imam. (2016). Aplikasi Analisis Multivariete Dengan Program. IBM SPSS (Edisi 8). Cetakan ke VIII. Semarang : Badan Penerbit.

Harun, H. (2015). Indonesian Public Sector Accounting Reforms: Dialogic Aspirations A Step Too Far?. Accounting, Auditing \& Accountability Journal, 28 (5), pp:706-738.

Hafidhah, \& Herli, M. (2014). Pengaruh Budaya Organisasi, dan Akuntabilitas Publik terhadap Kinerja Rumah Sakit di Kabupaten 
Sumenep. PERFORMANCE, 3(2), 8-17.

Judarmita. (2016). Pengaruh Kejelasan Sasaran Anggaran, Sistem Pelaporan Dan Audit Kinerja Terhadap Akuntabilitas Pengelolaan Dana Desa Di Kabupaten Badung. E-Journal Akuntansi Universitas Udayana. 21(3).

Kenis, I. 1979. Effect on Budgetary Goal Characteristic on Managerial Attitudes and Performance.The Accounting Review, Vol. LIV, No. 4, pp: 707-721

Kaltsum, U., \& Abdul, R. (2012). Pengaruh Kejelasan Sasaran Anggaran Terhadap Akuntabilitas Kinerja Instansi Pemerintah Melalui Sistem Pengendalian Intern Sebagai Variabel Intervening (Studi Empiris pada Satuan Kerja Perangkat Daerah Kota Salatiga). Diponegoro Journal of Accounting, 1(1), 1-14.

Kewo, Cecilia Lelly. (2014). The Effect of Participative Budgeting, Budget Goal Clarity and Internal Control Implementation on Managerial Performance.. Research Journal of Finance and Accounting. Accounting Doctoral Program Faculty of Economic and Business Padjadjaran UniversityIndonesia. 5 (12).

Khasanah, D. N. (2016). Pengaruh Kejelasan Sasaran Anggaran, Budaya Organisasi, Pengendalian Akuntansi, Sistem Pelaporan, dan Motivasi Kerja Terhadap Akuntabilitas Kinejra Instansi Pemerintah (Studi Kasus Pada SKPD Dinas di Kota Surakarta). E-Jurnal FEB Universitas Surakarta, 147, 11-40.

Kreitner, R. \& Kinicki, A. (2003). Perilaku Organisasi. Edisi Bahasa Indonesia, Jakarta : Salemba Empat.

Lesmana, D. \& Mutiara M. (2014). Pengaruh Kejelasan Sasaran Anggaran, Sistem Pengendalian Akuntansi dan Sistem Pelaporan Terhadap Akuntabilitas Kinerja dengan Kinerja Manajerial Sebagai Variabel Moderasi pada Instansi Pemerintahan Kota Palembang. Jurnal Akuntansi. Sekolah Tinggi Ilmu Ekonomi Musi Palembang. Buletin Ekonomi, 12(1) pp.1-12.

Mardiasmo. (2009). Akuntansi Sektor Publik, Cetakan ke empat. Penerbit Andi: Yogyakarta.

Mardiani, S., \& Edi, S. T. (2017). Pengaruh Fraud Diamond terhadap Pendeteksian Financial Statement Fraud dengan Komite Audit Sebagai Variabel Moderasi (pada Perusahaan Sub Sektor Farmasi yang Terdaftar di Bursa Efek Indonesia). Prosiding Akuntansi, 3(2), 476-484.

Mulyati, S., Lilik, H., \& Irwan, M. (2017). Determinants Accountability of Government Agencies Performance. E-Proceeding STIE Mandala Jember. International Conference and Call for Papers, Jember.

Monfardini, Patrizio. 2010. Accountability In The New Publicsector: A Comparative Case Study. International Journal of Public Sector Management, 23 (7), pp:632-646.

Mulgan, Richard. 2008. Public Sector Reform In New Zealand: Issues Of Public Accountability. Australian National University, Australia.

Okeke, Remi Chukwudi, Sylvia Uchenna Agu. 2016. Institutional Mechanisms For Local Government Accountability: Evaluating The Nigerian Provisions Against The European Charter Of Local Self- 
Government. World ScientificNews 40. pp:284-299.

Osakede, K., Ijimakinwa S., \& Adesanya T. (2016). Local Government Financial Autonomy In Nigeria: An Empirical Analysis. Kuwait Chapter of Arabian Journal of Business and Management Review, 5 (11), pp:24-37.

Pangumbalerang, A., \& Pinatik, S. (2014). Kejelasan Sasaran Anggaran Terhadap Akuntabilitas Kinerja Instansi Pemerintah Pada Dinas Pendapatan Daerah dan Badan Pengelolaan Keuangan dan Barang Milik Daerah. Jurnal EMBA, 2(2), 800-808.

Paramitha, I. A. M. D., \& Gayatri. (2016). Pengaruh Ketepatan Sasaran Anggaran, Sistem Pengendalian Manajerial Sektor Publik dan Sistem Pelaporan Pada Akuntabilitas Kinerja. E-Jurnal Akuntansi, 16(3), 24572479.

Peraturan Presiden No 29 Tahun 2014 tentang Sistem Akuntabilitas Kinerja Instansi Pemerintah.

Peraturan Pemerintah No. 18 Tahun 2016 tentang Pemerintahan Daerah.

Perawati, K. M. (2018). Pengaruh Gaya Kepemimpinan Transformasional, Budaya Organisasi, dan Komitmen Organisasi Pada Kinerja Organisasi. E-Journal Akuntansi Universitas Udayana. 12(5).

Perwirasari, F. B. P. (2016). Faktor-Faktor yang Mempengaruhi Akuntabilitas Kinerja Instansi Pemerintah. Unnes Education Journal. Jurusan Akuntansi Fakultas Ekonomi Universitas Negeri Semarang.

Primayoni, N. K. R., Adiputra, I. M. P., \& Sujana, E. (2014). Pengaruh Kejelasan Sasaran Anggaran dan Efektivitas Pengendalian Intrnal Terhadap Akuntabilitas Kinerja Instansi Pemerintah (Studi Kasus pada SKPD Kabupaten Klungkung). E-Journal S1 Ak Universitas Pendidikan Ganesha, 2(1).

Riantiarno, R. \& Nur A. (2011). Faktor-Faktor Yang Mempengaruhi Akuntabilitas Kinerja Instansi Pemerintah.. Pekbis Jurnal Universitas Riau 3(3).

Ritonga, R. (2013). Optimalisasi Audit Kinerja Instansi Pemerintah. http:/ / sumut.kemenag.go.id (diakses pada tanggal 1 April 2018)

Shah, A. (2014). Responsibility With Accountability: A FAIR Governance Framework For Performance Accountability Of Local Governments. Journal of Zbornik Radova Ekonomskog Fakulteta u Rijeci, 32(2), pp:343-377

Setiawan, E., Andreas, \& Rusli. (2013). Pengaruh Kejelasan Sasaran Anggaran, Pengendalian Akuntansi dan Sistem Pelaporan Terhadap Akuntabilitas Kinerja Pemerintah. Jurnal Akuntansi Fakultas Ekonomi Universitas Riau.

Sugiyono. (2017). Metode Penelitian Kuantitatif, Kualitatif dan R\&D. Bandung: PT Alfabet.

Sutoyo, \& Mahardhika, D. (2015). Pengaruh Sistem Pengendalian Manajemen dan Budaya Organisasi Terhadap Kinerja Organisasi (Studi Kasus Pada Pemerintah Daerah Provinsi Daerah Istimewa Yogyakarta). Buletin Ekonomi. Program Studi Akuntansi Fakultas Ekonomi Universitas Pembangunan Nasional "Veteran Yogyakarta 13(2). 
Suwandi, A. P. (2013). Pengaruh Kejelasan Sasaran Anggaran dan Desentralisasi Terhadap Kinerja Pemerintah Daerah (Studi Empiris pada SKPD Pemerintah Kota Padang). Artikel Ilmiah Fakultas Ekonomi Universitas Negeri Padang.

Susilowati, H. (2014). Pengaruh Kejelasan Sasaran Anggaran, Pengendalian Akuntansi, Sistem Pelaporan, dan Motivasi Kerja Terhadap Akuntabilitas Kinerja Instansi Pemerintah Daerah (Studi Kasus Pada Dinas Pemerintah Daerah Kota Surakarta). Universitas Muhammadiyah Surakarta

Tresnawati, R. (2012). Pengaruh Efektifitas Pengendalian Intern Terhadap Kinerja Instansi Pemerintah Di Dinas Pendapatan Daerah Kota Bandung. Prosiding Seminar Nasional. Universitas Widyatama.

Triuriana, E. A. (2013). Faktor-faktor yang Mempengaruhi Akuntabilitas Kinerja Instansi Pemerintah (Studi Empiris pada Kabupaten Jember). Artikel Ilmiah Mahasiswa.

Undang-Undang Nomor 23 Tahun 2014 tentang Pemerintah Daerah. Undang-Undang Nomor 17 Tahun 2003 tentang Keuangan Negara.

Wijaya, A. H. C., \& Akbar, R. (2013). The Influence of Information, Organizational Objectives and Targets, and External Pressure Towards The Adoption of Performance Measurement System in Public Sector. Journal of Indonesian Economy and Business, 28(1), 62-83.

Wirama, Y. (2018). Pengaruh Pengelolaan Keuangan Daerah Terhadap Akuntabilitas Kinerja Pada Satuan Kerja Perangkat Daerah Kabupaten Badung. E-Journal Akuntansi Universitas Udayana. 3 (2).

Yulianti, R. (2014). Pengaruh Kejelasan Sasaran Anggaran, Kesulitan Sasaran Anggaran, Pengendalian Akuntansi dan Sistem Pelaporan Terhadap Akuntabilitas Kinerja Instansi Pemerintah. Jurnal Online Mahasiswa (JOM) Fekon, 1(2), 1-15. 